\title{
Binary Iodides and Polyethylene Oxide (PE0) Based Gel Polymer Electrolyte for Dye Sensitized Solar Cells
}

\author{
Bandara TMWJ*, Nishshanke GBMMM and Thilakarathna BDKK \\ Department of Physics and Postgraduate Institute of Science, University of Peradeniya, Sri Lanka
}

*Corresponding author: Bandara TMWJ, Department of Physics and Postgraduate Institute of Science, University of Peradeniya, Peradeniya, Sri Lanka

\begin{abstract}
The stability in dye-sensitized solar cells (DSCs) can be improved by replacing their liquid electrolytes by gel polymer electrolytes. Gel polymer electrolytes, containing binary iodides having small and large cations improve, efficiency in DSCs without degrading the mechanical properties of the electrolyte. A new gel polymer electrolyte, suitable for DSCs, is prepared with PEO and binary salts LiI and tetrapropylammonium iodide. The conductivity in the electrolyte is $3.48 \mathrm{mS} \mathrm{cm}^{-1}$ at $25{ }^{\circ} \mathrm{C}$ and it increases gradually with increasing temperature. The temperature dependence of conductivity of this PEO based gel electrolyte follows the

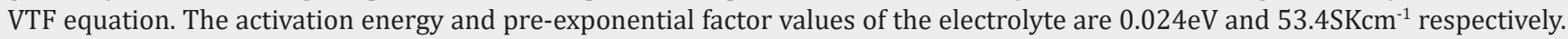
Solar cell assembled with this new gel polymer electrolyte exhibits very good short-term stability. The short circuit current density, the open circuit voltage and the energy conversion efficiency the DSC are $11.2 \mathrm{~mA} \mathrm{~cm}^{-2}, 0.674 \mathrm{~V}$ and $5.18 \%$ respectively.
\end{abstract}

Keywords: Mixed cation effect; Polymer electrolyte; Dye sensitized solar cells; Counter ion; Gel electrolyte: Binary salt

\section{Introduction}

There are immense benefits of improving low-cost dyesensitized solar cells (DSCs) since solar energy is a promising renewable energy resource [1,2]. DSCs based on gel polymer electrolytes or quasi solid state DSCs gain high attention as they overcome the limitations of liquid electrolytes such as leakage and high evaporation rates $[3,4]$. A lot of research has been conducted to improve properties of electrolyte that enhances efficiency in DSC. Improving ionic conductivity by incorporation of plasticizers into polymer electrolytes is a common example [5,6]. However, addition of excessive amount of plasticizers degrades the mechanical properties of the electrolyte and thus destroys the gel nature of the electrolyte [7]. Later, the effect of cations (counter ion) in the electrolyte for efficiency in DSCs was identified [8,9]. Generally, open circuit voltage $\left(\mathrm{V}_{\mathrm{oc}}\right)$ increases with increasing radius of counter ion while short circuit current density $\left(\mathrm{J}_{\mathrm{sc}}\right)$ have a tendency to increase with decreasing size of the counter ion in liquid electrolyte of DSCs [9]. This behavior has been confirmed for quasi-solid-state DSCs as well $[10,11]$. In 2012, the authors reported a method to enhance efficiency in quasi-solid-state DSC by capitalizing the mixed salt effect [12]. The method is important since it provides a way to improve efficiency in DSCs without degrading the mechanical properties of the electrolyte. Subsequently, many authors have reported efficiency enhancements in quasi solidstate DSCs capitalizing the mixed cation effect using host polymers such as Polyacrylonitrile (PAN), Polyvinylidenefluoride (PVDF), Polyvinylalcohol (PVA), Polymethylmethacrylate (PMMA) and Phthaloylchitosan [13-16]. In these studies, a number of salt combinations have been tried out in order to improve the solar cell performance. The present study reports a polyethylene oxide (PEO) based gel polymer electrolyte with the binary salts LiI and Tetrapropylammonium iodide, $\left(\left(\mathrm{CH}_{3} \mathrm{CH}_{2} \mathrm{CH}_{2}\right)_{4} \mathrm{NI}\right)$ suitable for highly efficient DSCs.

\section{Experimental}

Materials: LiI, $\left(\mathrm{CH}_{3} \mathrm{CH}_{2} \mathrm{CH}_{2}\right) 4 \mathrm{NI}$, (PEO) (Mw, 4,000,000), iodine (I2), ethylene carbonate (EC) and propylene carbonate (PC), all purchased from Aldrich (purity > 98\%). Prior to use, PEO and salts were vacuum dried for $\sim 24 \mathrm{~h}$ at $50{ }^{\circ} \mathrm{C}$. Conducting glass, fluorine doped tin oxide (FTO) with a sheet resistance of $7 \Omega \mathrm{cm}^{-2}$ and sensitizing dye, ruthenium 535-bis TBA, were purchased from Solaronix $\mathrm{SA} \mathrm{TiO}_{2}$ nano particles P25 (particle size $\sim 21 \mathrm{~nm}$ ) and P90 (particle size $\sim 14 \mathrm{~nm}$ ), were from the Evonik, Germany. 


\section{Electrolyte preparation}

Gel electrolyte was prepared according to the stoichiometric formula $\left.(\mathrm{EO})_{10}(\mathrm{EC})_{50}(\mathrm{PC})_{40}(\mathrm{LI})_{1.2}\left(\mathrm{CH}_{3} \mathrm{CH}_{2} \mathrm{CH}_{2}\right)_{4} \mathrm{NI}\right)_{0.8}(\mathrm{I} 2)_{0.2}$, where (EO) represents one monomer of PEO. The composition of the electrolyte is given in (Table 1). In addition, performance enhancers, $0.126 \mathrm{~g}$ of 1-methyl-3-propyl imidazolium iodide (MPII) and $0.217 \mathrm{~g}$ of 4-tert-butylpyridine (4TBP), were also added to the electrolyte. For the electrolyte preparation, all the ingredients except PEO and $\mathrm{I}_{2}$ were mixed (stirred $6 \mathrm{~h}$ ) in a closed vial. Then PEO was added and stirred at $80^{\circ} \mathrm{C}$ for half an hour. Finally, $\mathrm{I}_{2}$ was added and stirred for another half an hour at room temperature in order to get the gel polymer electrolyte.

Table 1: Composition of the gel polymer electrolyte.

\begin{tabular}{|c|c|c|c|c|c|c|}
\hline Component & PEO & LiI & $\mathbf{C H}_{\mathbf{3}} \mathbf{C H}_{\mathbf{2}} \mathbf{C H}_{\mathbf{2}} \mathbf{~}_{\mathbf{4}} \mathbf{N I}$ & EC & PC & Iodine \\
\hline Weight / g & 1 & 0.304 & 0.472 & 8.302 & 7.701 & 0.1 \\
\hline Molar fraction & 10 & 1.2 & 0.8 & 50 & 40 & 0.2 \\
\hline
\end{tabular}

\section{Fabrication of DSC}

In order to prepare the $\mathrm{TiO}_{2}$ photo-anode two layers of $\mathrm{TiO}_{2}$ were coated on FTO substrates using $\mathrm{TiO}_{2}$ nanoparticles with different sizes. The $1^{\text {st }}$ layer was spin-coated on the FTO substrate using slurry containing (P90). The $2^{\text {nd }}$ layer was coated on the $1^{\text {st }}$ layer with slurry containing $21 \mathrm{~nm}$ particle size (P25). The photo-electrode preparation is described in detail in a previously published work [17]. For the photo-sensitization, $\mathrm{TiO}_{2}$ coated glass plate was immersed in a warm $0.5 \mathrm{mM}$ solution of ruthenium 535-bis TBA (N719 dye) in ethanol and kept for $\sim 24 \mathrm{~h}$ at room temperature. After taking out, the dye-adsorbed $\mathrm{TiO}_{2}$ electrode was rinsed with acetone. The gel polymer electrolyte was spread on the dye-sensitized double-layered $\mathrm{TiO}_{2}$ electrode. Then a platinum (Pt) coated glass plate was pressed on it to complete the DSC assembly.

\section{Measurements}

The complex impedance was taken using an Autolab PGSTAT128N module with Nova software in the $10 \mu \mathrm{Hz}$ to $32 \mathrm{MHz}$ frequency range at different temperatures. For this purpose, electrolyte samples were sandwiched between two stainless steel electrodes. The DSCs were irradiated by a LOT-Oriel $\mathrm{GmbH}$ solar simulator at $1.5 \mathrm{AM}, 1000 \mathrm{Wm}^{-2}$. The current-voltage (I-V) characteristics of the cells were also obtained using the Autolab PGSTAT128N module and Nova software. The area of the cell exposed to light was $12 \mathrm{~mm}^{2}$ and the potential scan rate was $10 \mathrm{mV}$ $\mathrm{s}^{-1}$. current-voltage data were measured for about $1 \mathrm{~h}$ ( $5 \mathrm{~min}$ steps) under continued irradiation.

\section{Results and Discussion}

\section{Electrolyte conductivity}

Complex impedance analysis was used to obtain buck resistance of the electrolyte in order to calculate the ionic conductivity in the electrolyte at each temperature. For this purpose, Nyquist plots were used. The conductivity in the electrolyte is $3.48 \mathrm{mS} \mathrm{cm}^{-1}$ at $25{ }^{\circ} \mathrm{C}$ and it increases gradually with increasing temperature. Consequently, ionic conductivity reaches to $4.77 \mathrm{mS} \mathrm{cm}^{-1}$ at $50{ }^{\circ} \mathrm{C}$. Ionic conductivity variation with temperature in this PEO based gel polymer electrolyte is shown in (Figure 1). Conductivity $(\sigma)$ increases with increasing temperature, however the temperature dependence of $\sigma$ is non-Arrhenius as shown in (Figure 1). Since
Figure 1 exhibits non-Arrhenius behavior, $\ln \left(\sigma \mathrm{T}^{1 / 2}\right)$ is plotted as a function of $\left(\mathrm{T}-\mathrm{T}_{0}\right)$ (Figure 2$)$ in order to understand the temperature dependence of the conductivity. $\mathrm{T}$ is absolute temperature and $\mathrm{T}_{0}$ is the ideal glass transition temperature. In case, measured glass transition temperature $170 \mathrm{~K}$ was used as $\mathrm{T}_{0}$. As seen from (Figure 2) the temperature dependence of conductivity in this PEO based gel electrolyte follows the Vogel-Tammann-Fulcher (VTF) $[18,19]$ behavior. Thus, the data were fitted to the VTF equation,

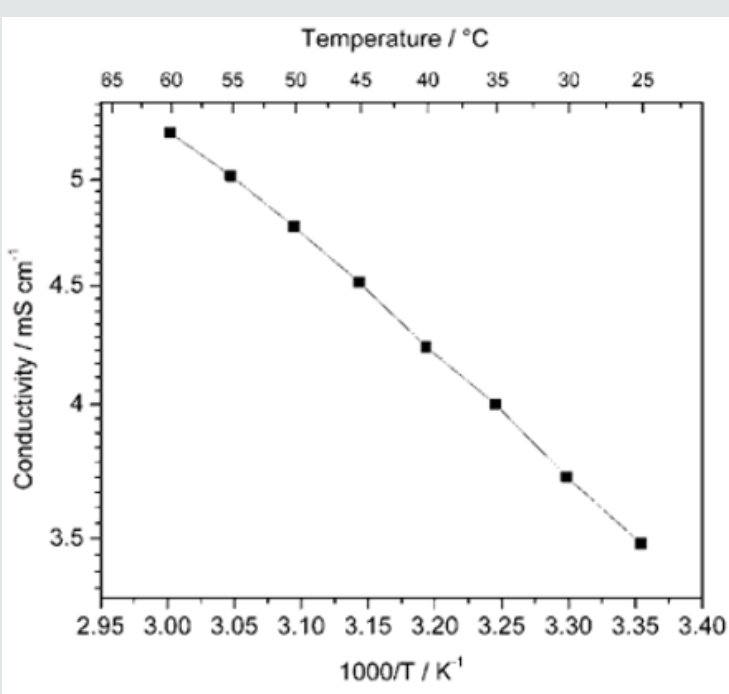

Figure 1: The temperate dependence of ionic conductivity in the PEO based gel polymer electrolyte $(\mathrm{EO})_{10}(\mathrm{EC})_{50}$ $\left.(\mathrm{PC})_{40}(\mathrm{LI})_{1.2}\left(\mathrm{CH}_{3} \mathrm{CH}_{2} \mathrm{CH}_{2}\right)_{4} \mathrm{NI}\right)_{0.8}(\mathrm{I} 2)_{0.2}$.

$$
\sigma(T)=A T^{-\frac{1}{2}} \exp \left[\frac{-E_{a}}{K_{B}\left(T-T_{0}\right)}\right]
$$

where, $\mathrm{E}_{\mathrm{a}^{\prime}} \mathrm{A}$ and $\mathrm{k}$ are pseudo-activation energy, pre-exponential factor and the Boltzmann constant respectively. The estimated Ea and $A$ values of the electrolyte are $(0.024 \pm 0.0002) \mathrm{eV}$ and $(53.4 \pm 1) \mathrm{S}$ $\mathrm{K} \mathrm{cm}^{-1}$ respectively.

Quasi-solid-state DSC prepared using a $\mathrm{TiO}_{2}$ double layer photoelectrode and $(\mathrm{EO})_{10}(\mathrm{EC})_{50}(\mathrm{PC})_{40}(\mathrm{LI})_{1.2}\left(\mathrm{CH}_{3} \mathrm{CH}_{2} \mathrm{CH}_{2}\right)_{4}(\mathrm{NI})_{0.8}(\mathrm{I} 2)_{0.2}$ electrolyte is characterized using current density versus cell potential (J-V) curves (Figure 3). The measurements were taken for about one hour under continues irradiation in order to check the short-term stability of the cell performance. As seen from 
(Figure 4), the photo-current density has indeed increased with the irradiation time, which can be an artifact of temperature increase with irradiation time. As seen from (Figure 1) ionic conductivity increases with increasing temperature and thus small increase in temperature with irradiation time can reduce resistive losses in the cell. The excellent short-term stability exhibited by cell highlights the advantage of the gel polymer electrolyte used in this work. This can be attributed to avoiding volatile liquids in the electrolyte and the ability of PEO to retain the solvents. J-V characteristic curves were used to determine the short circuit current density $\left(\mathrm{J}_{\mathrm{sc}}\right)$, the open-circuit voltage $\left(\mathrm{V}_{\mathrm{oc}}\right)$, the fill factor (ff) and the energy conversion efficiency ( $\eta \%)$. The calculated $J_{s c^{\prime}}, V_{o c^{\prime}}$ ff and $\eta \%$ values of the DSSC series are given in (Table 2) together with the irradiation time.

Table 2: The performance parameters of DSCs with irradiation time.

\begin{tabular}{|c|c|c|c|c|}
\hline Time & $\mathbf{J}_{\mathbf{s c}} / \mathbf{m A ~ c m}^{-\mathbf{2}}$ & $\mathbf{V}_{\mathbf{o c}} / \mathbf{V}$ & $\mathbf{f f} / \mathbf{\%}$ & Efficiency / \% \\
\hline 5 & 11.2 & 0.675 & 68.5 & 5.17 \\
\hline 10 & 11.2 & 0.675 & 68.7 & 5.18 \\
\hline 15 & 11.1 & 0.675 & 69.3 & 5.2 \\
\hline 20 & 11.3 & 0.675 & 68.4 & 5.2 \\
\hline 25 & 11.2 & 0.675 & 69 & 5.2 \\
\hline 30 & 11.2 & 0.675 & 68.8 & 5.19 \\
\hline 35 & 11.1 & 0.675 & 68.8 & 5.18 \\
\hline 40 & 11.2 & 0.675 & 68.5 & 5.16 \\
\hline 45 & 11.2 & 0.67 & 68.9 & 5.15 \\
\hline 50 & 11.2 & 0.67 & 68.4 & 5.15 \\
\hline 55 & 11.3 & 0.67 & 68.1 & 5.15 \\
\hline Average & 11.2 & 0.674 & 68.67 & 5.18 \\
\hline
\end{tabular}

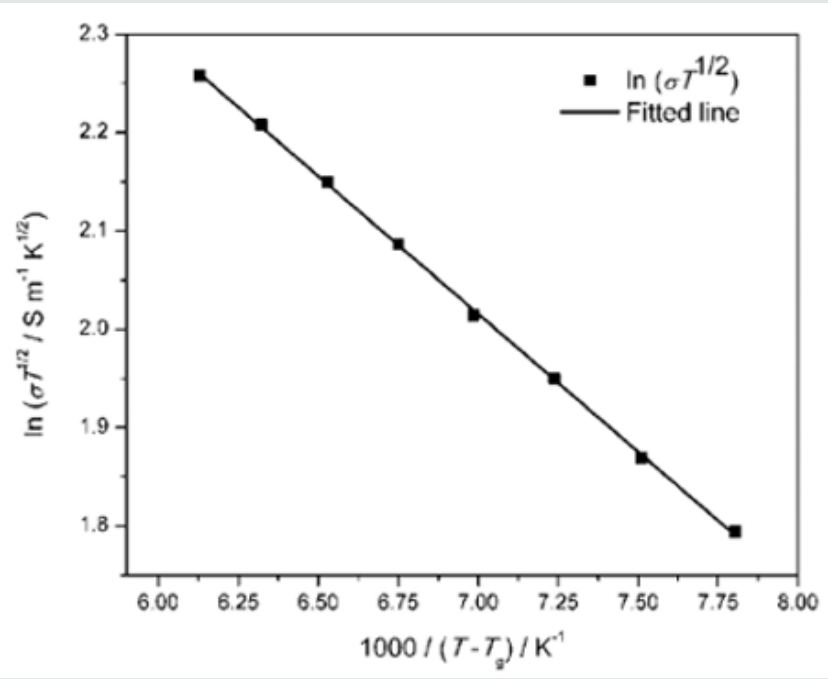

Figure 2: $\sigma T^{1 / 2}$ versus $1000 /(\mathrm{T}-\mathrm{T} 0)$ for $(\mathrm{EO})_{10}(\mathrm{EC})_{50}(\mathrm{PC})_{40}$ $\left.(\mathrm{LI})_{12}\left(\mathrm{CH}_{3} \mathrm{CH}_{2} \mathrm{CH}_{2}\right)_{4} \mathrm{NI}\right)_{0.8}(\mathrm{I} 2)_{0.2}$ electrolyte. The square symbols represent experimental data.

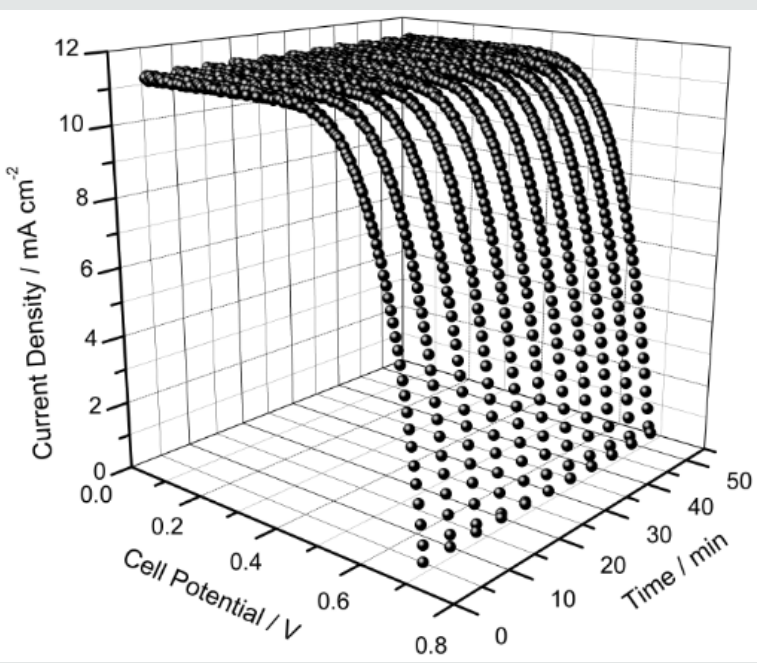

Figure 3: The photocurrent density versus potential as a function of irradiation time of the DSC containing $\left.(\mathrm{EO})_{10}(\mathrm{EC})_{50}(\mathrm{PC})_{40}(\mathrm{LI})_{1.2}\left(\mathrm{CH}_{3} \mathrm{CH}_{2} \mathrm{CH}_{2}\right)_{4} \mathrm{NI}\right)_{0.8}(\mathrm{I} 2)_{0.2}$ electrolyte. Measurements were taken under irradiation of $1000 \mathrm{~W} \mathrm{~m}-2$ (1.5 AM).

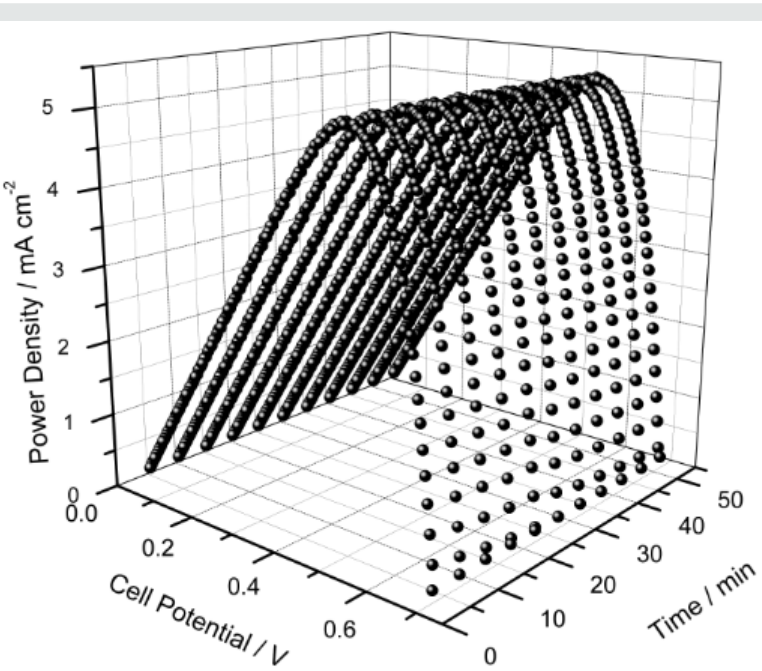

Figure 4: The Power density versus cell potential as a function of irradiation time of the DSC containing $\left.(\mathrm{EO})_{10}(\mathrm{EC})_{50}(\mathrm{PC})_{40}(\mathrm{LI})_{1.2}\left(\mathrm{CH}_{3} \mathrm{CH}_{2} \mathrm{CH}_{2}\right)_{4} \mathrm{NI}\right)_{0.8}(\mathrm{I} 2)_{02}$ electrolyte. Measurements were taken under irradiation of $1000 \mathrm{~W} \mathrm{~m}-2$ (1.5 AM).

\section{Conclusion}

A new gel polymer electrolyte, composed of PEO and the binary salts LiI and tetrapropylammonium iodide, is suitable for efficient quasi solid-state DSC. The conductivity in the electrolyte is $3.48 \mathrm{mS}$ $\mathrm{cm}^{-1}$ at $25^{\circ} \mathrm{C}$ and it increases gradually with increasing temperature. Consequently, ionic conductivity reaches to $4.77 \mathrm{mS} \mathrm{cm}^{-1}$ at $50{ }^{\circ} \mathrm{C}$. The temperature dependence of conductivity in this PEO based gel electrolyte follows the Vogel-Tammann-Fulcher (VTF) behavior. The activation energy and pre-exponential factor of the electrolyte are $0.024 \mathrm{eV}$ and $53.4 \mathrm{~S} \mathrm{~K} \mathrm{~cm}^{-1}$ respectively. Solar cell assembled with this new gel polymer electrolyte exhibits very good short- 
term stability. The -average short circuit current density, the opencircuit voltage and the energy conversion efficiency the DSC are $11.2 \mathrm{~mA} \mathrm{~cm}^{-2}, 0.674 \mathrm{~V}$ and $5.18 \%$ respectively. The excellent shortterm stability exhibited by the cell can be attributed to avoiding volatile liquids in the electrolyte and the ability of PEO to hinder the evaporation of liquid components in the electrolyte.

\section{References}

1. Mehmood U, Rahman S, Harrabi K, Hussein IA, Reddy BVS (2014) Recent Advances in Dye Sensitized Solar Cells. J Advances in Materials Science and Engineering pp. 1-12.

2. Suait MS, Rahman MYA, Ahmad A (2015) Review on polymer electrolyte in dye-sensitized solar cells (DSSCs). J Solar Energy 115: 452-470.

3. Mahmood A (2015) Recent research progress on quasi-solid-state electrolytes for dye-sensitized solar cells. J Energy Chemistry 24(6): 686-692.

4. Jiang N, Sumitomo T, Lee T (2013) High temperature stability of dye solar cells. J Solar Energy Materials \& Solar Cells 119: 36-50.

5. Bella F, Popovic J, Lamberti A, Tresso E, Gerbaldi C, et al. (2017) Interfacial effects in solid-liquid electrolytes for improved stability and performance of dye-sensitized solar cells. J ACS Appl Mater Interfaces 9(43): 37797-37803.

6. Ho Soonmin, Mariyappan S, Meet M, Jaysukh HM (2018) Review on dyesensitized solar cells based on polymer electrolytes. Intl J Engineering \& Technology 7(4): 3001-3006.

7. Bandara TMWJ, Svensson T, Dissanayake MAKL, Furlani M, Jayasundara et al. (2012) Tetrahexylammonium iodide containing solid and gel polymer electrolytes for dye sensitized solar cells. Energy Procedia 14: 1607-1612.

8. Watson DF, Meyer GJ (2014) Cation effects in nanocrystalline solar cells. J Coordination Chemistry Reviews 248(13-14): 1391-1406.

9. Liu Y, Hagfeldt A, Xiao XR, Lindquist SE (1998) Investigation of influence of redox species on the interfacial energetics of a dye-sensitized nanoporous $\mathrm{TiO}_{2}$ solar cell. J Solar Energy Materials \& Solar Cells 55(3): 267-281.

10. Bandara TMWJ, Jayasundara WJMJSR, Dissanayake MAKL, Furlani M, Albinsson I, et al. (2013) Effect of cation size on the performance of dye sensitized nanocrystalline $\mathrm{TiO}_{2}$ solar cells based on quasi-solid state PAN electrolytes containing quaternary ammonium iodides. J Electrochimica Acta 109: 609-616.

11. Bandara TMWJ, Fernando HDNS, Furlani M, Albinsson I, Ratnasekera JL, et al. (2017) Combined Effect of Alkaline Cations and Organic Additives for Iodide Ion Conducting Gel Polymer Electrolytes to Enhance Efficiency in Dye Sensitized Solar Cells. J Electrochimica Acta 252: 208-214.

12. Bandara TMWJ, Dissanayake MAKL, Jayasundara WJMJSR, Albinsson I Mellander BE (2012) Efficiency enhancement in dye sensitized solar cells using gel polymer electrolytes based on a tetrahexylammonium iodide and MgI2 binary iodide system. J Phys Chem Chem Phys 14(24): 8620-8627.

13. Aziz MF, Buraidah MH, Careem MA, Arof AK (2015) PVA based gel polymer electrolytes with mixed iodide salts (K+I- and Bu4N+I-) for dyesensitized solar cell application. Electrochim Acta182: 217-223.

14. Arof AK, Aziz MF, Noor MM, Careem MA, Bandara LRAK, et al. (2014) Efficiency enhancement by mixed cation effect in dye-sensitized solar cells with a PVdF based gel polymer electrolyte. Int J Hydrogen Energy 39(6): 2929-2935.

15. Teo LP, Tiong TS, Buraidah MH, Arof AK (2018) Effect of lithium iodide on the performance of dye sensitized solar cells ( DSSC ) using poly ( ethylene oxide ) ( PEO )/ poly ( vinyl alcohol) ( PVA ) based gel polymer electrolytes. Optical Materials 85: 531-537.

16. Careem MA, Aziz MF, Buraidah MH (2017) Boosting Efficiencies of Gel Polymer Electrolyte Based Dye Sensitized Solar Cells Using Mixed Cations. Mater Today Proc 4(4): 5092-5099.

17. Bandara TMWJ, Jayasundara WJMJSR, Fernando HDNS, Dissanayake MAKL, De Silva LAA, et al. (2014) Efficiency enhancement of dyesensitized solar cells with PAN: CsI: LiI quasi-solid state (gel) electrolytes. Journal of Applied Electrochemistry. J Appl Electrochem 44(8): 917-926.

18. Aziz SB, Woo TJ, Kadir MFZ, Ahmed HM (2018) A conceptual review on polymer electrolytes and ion transport models. Journal of Science: Advanced Materials and Devices 3(1): 1-17.

19. Bandara TMWJ, Jayasundara WJMJSR, Dissanayake MAKL, Fernando HDNS, Furlani M, et al. (2014) Quasi solid state polymer electrolyte with binary iodide salts for photo-electrochemical solar cells. J Hydrogen Energy 39(6): 2997-3004.

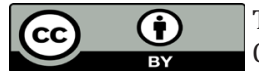

This work is licensed under Creative Commons Attribution 4.0 License

To Submit Your Article Click Here: Submit Article

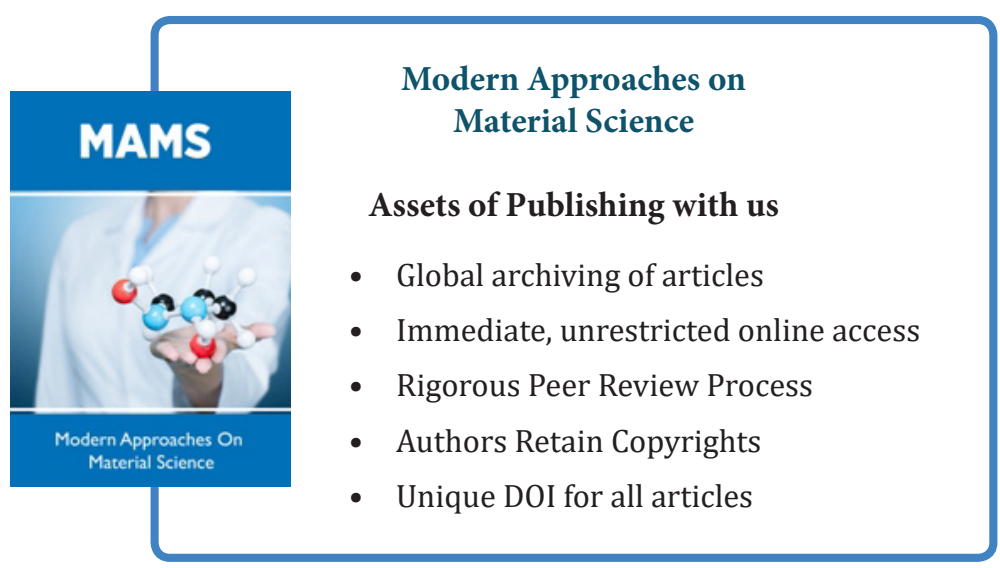

